Relations industrielles

Industrial Relations

\title{
Charles J. MCMILLAN : The Japanese Industrial System. Berlin-New York, Walter de Gruyter, 1984, 356 pp., ISBN 3-11-008894-0
}

\section{Alexander J. Matejko}

\section{Volume 39, numéro 4, 1984}

URI : https://id.erudit.org/iderudit/050089ar

DOI : https://doi.org/10.7202/050089ar

Aller au sommaire du numéro

Éditeur(s)

Département des relations industrielles de l'Université Laval

ISSN

0034-379X (imprimé)

1703-8138 (numérique)

Découvrir la revue

Citer ce compte rendu

Matejko, A. J. (1984). Compte rendu de [Charles J. MCMILLAN : The Japanese Industrial System. Berlin-New York, Walter de Gruyter, 1984, 356 pp., ISBN 3-11-008894-0]. Relations industrielles / Industrial Relations, 39(4), 799-801. https://doi.org/10.7202/050089ar

Tous droits réservés (C) Département des relations industrielles de l'Université Laval, 1984
Ce document est protégé par la loi sur le droit d'auteur. L’utilisation des services d'Érudit (y compris la reproduction) est assujettie à sa politique d'utilisation que vous pouvez consulter en ligne.

https://apropos.erudit.org/fr/usagers/politique-dutilisation/ 
et sociales, mais de cette expérience "ron ne voit pas encore clair sur la façon dont la combinaison des intérêts de tous les intervenants dans le processus de décision de l'entreprise va aider ce dernier à répondre aux conditions économiques changeantes». Selon moi, c'est au moins la raison pour laquelle il faut poursuivre le travail d'amélioration des relations industrielles au niveau international.

Le plan de l'ouvrage est le suivant. L'introduction (chapitre $1^{\mathrm{er}}$ ) rappelle le rôle et la composition des organes de contrôle des principes directeurs au sein de l'OCDE ainsi que la première révision des principes en 1979. Le chapitre II procure un aperçu général et très bref de ce qui a été accompli par les multinationales dans les domaines de l'emploi (création d'emplois) et des relations industrielles (organisation décentralisée). À notre avis, ce chapitre n'était pas indispensable car il évoque et cite trop brièvement ces questions et d'autres études qui leur ont déjà été consacrées. Les chapitres III à XII confrontent chacun des principes directeurs relatifs à l'emploi et aux relations professionnelles à la richesse des lois et pratiques au niveau national, principalement des Etats-Unis et des pays membres de la Communauté européenne, le but étant de discuter la gamme de significations contenues dans chacun des principes dans les contextes locaux. Dans ces chapitres, divers cas soumis au Comité précité sont discutés en détail. Le chapitre final conclut par quelques réflexions sur le caractère volontaire des principes directeurs, la fonction des relations industrielles («industrial relations function») et la signification de la "clause chapeau» de ces principes, en vertu de laquelle les entreprises devraient adhérer aux principes directeurs "dans le cadre de la législation, de la réglementation et des pratiques courantes en matière d'emploi et de relations avec les travailleurs dans chacun des pays où elles opèrent». L'ouvrage contient ensuite les trois annexes que nous avons évoquées.

François VANDAMME

Représentation permanente de la Belgique auprès des Communautés européennes.
The Japanese Industrial System by Charles J. McMillan, Berlin - New York: Walter de Gruyter, 1984, pp. XII + 356, ISBN 3-11-008894-0

«... We Japanese have no principles. Some people think we hide our intentions, but we have no intentions to hide. Except for some few leftists or rightists, we have no dogma and don't ourselves know where we are going" - stated over 10 years ago $\mathrm{Ch}$. Nakane (Newsweek, 1973, October 15th:60) and this seems to be valid also today. The industrial systems of Japan as described by McMillan appears as a practical arrangement based on careful planning done by government and the corporations closely cooperating with it.

There is a massive shift in Japan towards a highly modernized industrial structure based on the 'hardware' technology (electronics, etc.) and at the same time maintaining several traditional 'software' systems of management. "In what Japanese truly believe is a new industrial revolution in the form of microelectronics, the general direction of the country's evolution thus takes on the form of strategies emerging piecemeal, haphazardly, sometimes with luck, guile, and even questionable legalities» (p. 15).

Only one tenth of the economy depends on export but Japan has managed to improve much her position in the world market. In house training in administration and science has been practiced vary successfully for many years. The governmental structure is so designed that it orients the national economy towards the international trends. There is much room for internal pluralism, competitiveness and innovation but the facade of cooperation and consensus is well maintained. "The Japanese have developed work systems which combine human intellectual effort with machine precision and computational facility in a way unrivalled by Western societies. It is not hardware alone, nor software alone - it is both» (p. 41). The business-government relationship is very close and this much contributes to the growth. "Japan's industrial policy is one of orchestrating national levers-taxation, bank- 
ing, monetary and fiscal measures, administrative guidance, science policy, and the like into a coherent framework of investment decisions, for both big and small firms, public and private enterprises» (p. 63).

Japanese are particularly successful in emerging sunrise sectors or declining sunset sectors. It is up to government to promote competition by assuring several entrants in each sector. Japan traditionally imports foreign technology in order to learn or even resell. The highly developed managerial skills in Japan allow to absorb much on a selective basis. Continuous training in the companies helps to achieve an excellence. The very demanding educational system helps to keep standards high.

The long term perspective of the companies and their unique focus on achieving an internal harmony both help to keep business competitive. According to the author, «Japanese management combines many structural features of the American corporation, but incorporates a management philosophy nurturing individual commitment and corporate integration (...) Beneath the veneer of individual participation and involvement is a highly formalized system of financial controls and excellent information system (...) Human resource policies are integrated with other functions such as marketing, production, and finance» (pp. 168,189 ).

The fact that wages are a fixed cost in Japanese big companies makes necessary to follow policies of innovation and productivity improvement. Not only people are taken care of but there is also a growing tendency to depend on a highly sophisticated industrial engineering. They are widely using progress cost curves, time investing management, and robotics. "Shop floor work in Japan, as well as operations management, reflect many of the philosophical concerns expounded by Taylorism, including scientific decisionmaking and management-labour cooperation» (p. 226). The practitional local weaknesses of marketing become gradually eliminated. On the international markets Japan gains more and more learning ex. perience, and there is a growing emphasis on building their own banking basis. Among the world powers the place of Japan has changed very considerably: from one quarter Britain's per capita income in the early 1950 s to double as much now.

The author has done a very good job to present to the reader a clear picture how the economic success of Japan has been possible. On the other hand, he seems to underestimate the virtues of co-operation policy followed by big companies. There is also another side of patronalism widely practiced in Japan but less and less eagerly accepted by the young generation. P. McMillan mentions the fact that with the spread of education it becomes more difficult for graduates to find good careers at big corporations. In Japanese manufacturing almost three-fifths of all workers are employed by the establishments of 100 workers or less; the average number of employees per one manufactural establishment is 15 in comparison with 53 in Canada or the US and 80 in West Germany. These small companies are much dependent on the giants and have much less resources to accommodate their employees. Therefore, any generalizations based on big companies are not necessarily valid for the most of the Japanese workers and work establishments. This point is not enough clearly made in this book. Generosity for the relatively privileged part of the labour power is not extended to the rest, especially when the official social welfare programme remains modest.

There is much chance that with the economic and educational progress the individualistically articulated demands and aspirations of Japanese will grow; patronalism and an inferior position of trade unions may become more and more questioned, especially with the intensification of international competition and the deepening dependence of Japan on foreign raw materials. Of course, there are still many socio-psychological and structural predispositions making Japanese to work hard, save much, avoid the confrontation with 
bosses and buy the business creed preached by the employers. However, how long will it last actually?

The pragmatistic orientation of Japanese people and the evident advantages of the economic 'miracle' both work much in favour of playing safe and not rocking the boat. On the other hand, several undeniable assets of the existing system are already taken for granted. New aspirations growing among the young people are not necessarily fitting well into the status quo. The Japanese economy is much vulnerable to the international situation and any crisis on the world scale may have some very serious consequences for the internal balance of Japan. The fact that other nations more and more learn from the Japanese experience makes tougher the foreign trade. The resistance of Japan to accept the foreign penetration of internal markets creates a source of tension with trade partners. All these factors deserve more attention than this has been done in the book here under review.

\section{Alexander J. MATEJKO}

University of Alberta

Robots in Manufacturing: Key to International Competitiveness, par Jack Baranson, Mt Airy, Maryland, Lomond Publications Inc., 1983, 152 pp. ISBN 0-912338-39-3

Le titre de ce livre se traduit par: Les robots dans le secteur manufacturier: ouverture vers la compétition internationale. L'auteur, Jack Baranson, qui est président d'une firme de consultant (Developing World Industry and Technology, Inc.) étudie et présente de façon fort habile le sujet de: "Automatic Manufacturing Equipment and Systems (AMES)», soit la robotique ou les systèmes et les matériels de fabrication automatique. Bien sûr, l'orientation et la perspective sont «américaines».

\section{L'ouvrage est divisé en trois parties.}

La première constitue une mise en situation dont l'objet est triple: premièrement, un sermon prêchant l'importance de la fabrication automatisée; deuxièmement, un exposé très concis expliquant pourquoi les USA prennent du retard en ce domaine; et, troisièmement, une présentation de neuf recommandations visant à stimuler la concurrence américaine en matière de "AMES". Déjà en cette première partie, l'auteur établit une "configuration comparative» composée des USA, de l'Europe et, bien sûr, du Japon et qui va se retrouver ailleurs dans ce livre. On y note les bases de discussion et, ce qui est important, les facteurs reliés à la performance d'une nation quelconque par rapport à la fabrication automatisée: les conditions économiques générales, les relations entre l'industrie et le gouvernement, l'organisation et le management, les attitudes ouvrièrespatronales, etc. Des neuf recommandations avancées par l'auteur, nous avons remarqué la quatrième qui veut que le "renforcement" des industries à fabrication automatisée (les industries (AMES») ne peuvent se fier uniquement aux effets indirects des dépenses militaires.

La seconde partie du livre offre une analyse détaillée de facteurs établissant le taux d'adoption de la robotisation ou de la fabrication automatisée dans chacune des trois régions suivantes: les USA, l'Europe et le Japon. Le schéma de comparaison est exceptionnellement bien fait. Jack Baranson dégage et peint les "portraits» de chacune des régions mentionnées en fonction de trois ensembles de paramètres. Notamment, il décrit et analyse l'environnement national, les fournisseurs et les utilisateurs de la technologie "AMES». Son analyse touche les politiques industrielles gouvernementales, les structures et stratégies industrielles et les caractéristiques de gestion, ainsi que la demande des utilisateurs. Somme toute, cette deuxième partie est «l'explosion» du tableau synoptique présenté à la partie précédente. Au niveau du détail, il est intéressant de lire que présentement aux USA, deux sociétés seulement, Unimation et Cincinnati Milacron, se divisent $75 \%$ des ventes de robots! Heureusement - pour les USA -, on estime de 2 a 4 milliards de dollars le marché américain de systèmes de fabrication 